\title{
Penerapan Manajemen Risiko Operasional Pada Unit Teller Pada PT. Bank Pembangunan Daerah Sumatera Barat Cabang Lubuk Alung
}

\author{
Rika Wulandari, Romi Susanto \\ Akademi Keuangan dan Perbankan Padang \\ romisusanto@akbpstie.ac.id
}

\begin{abstract}
ABSTRAK
Penelitian ini dilakukan untuk mengetahui bagaimana penerapan manajemen risiko operasional pada unit teller yang dilaksanakan pada PT. Bank Pembangunan Daerah Sumatera Barat Cabang Lubuk Alung. Mengingat risiko operasional ini bukanlah jenis risiko baru yang dihadapi oleh sebuah bank karena risiko ini melekat dan terus berkembang pada kegiatan operasional bank. Penulis menggunakan metode kualitatif yang menjelaskan secara deskriptif yaitu dengan menguraikan data secara sistematis dari fakta-fakta yag didapat kemudian dihubungkan dengan penerapan manajemen risiko operasional pada unit teller pada PT. Bank Pembangunan Daerah Sumatera Barat Cabang Lubuk Alung. Penerapan Manajemen Risiko Operasional pada Unit Teller terlihat pada aktivitas harian yang dilakukan. Dimulai pada pagi hari dimana head teller yang mendapat wewenang untuk masuk khasanah akan melakukan serah terima cashbox kepada masing-masing teller yang bertanggung jawab sepenuhnya atas ini masing-masing cashbox, selanjutnya teller akan siap memulai aktivitas hariannya. Hasil penelitian menunjukkan bahwa Penerapan Manajemen Risiko Operasional yang dilakukan oleh PT. Bank Pembangunan Daerah Sumatera Barat Cabang Lubuk Alung telah sesuai dengan konsep-konsep yang telah ditetapkan oleh Bank Indonesia sehingga dapat menekan tingkat kerugian operasional. Penulis menyarankan agar Penerapan Manajemen Risiko Operasional harus lebih ditingkatkan dan pengawasan yang lebih ketat lagi.
\end{abstract}

Kata Kunci : Penerapan Manajemen Risiko Operasional, Unit Teller

\section{PENDAHULUAN}

Ancaman yang muncul dari dan terhadap kegiatan operasional bank dapat dipicu oleh berbagai factor baik internal maupun eksternal. Peristiwa potensial seperti penyalahgunaan wewenang (fraud), kegagalan system teknologi informasi, standar proses operasi yang belum sesuai dengan peraturan/regulasi yang berlaku, dan kejahatan pihak eksternal terhadap bank jika tidak diidentifikasi dan dikelola dengan baik dapat menimbulkan permasalahan yang berat bahkan bencana bagi bank. Dengan semakin maraknya kejahatan operasional perbankan akhir-akhir ini, telah menyadarkan semua pihak yang terlibat dalam kegiatan perbankan, mulai dari pihak bank, regulator, pemerintah dan nasabah. Dengan beberapa kejadian, menyadarkan semua pihak bahwa masih ada celah-celah (loop hole) yang masih harus ditutup dan terus disempurnakan, khususnyaoleh internal bank dan Bank Indonesia (BI) sebagai pengawas bank.

Kegiatan operasional merupakan kegiatan yang tidak dapat dipisahkan dari sebuah perusahaan, karena tanpa kegiatan ini sebuah perusahaan tidak akan dapat menjalankan aktivitasnya. Dan seiring perkembangan ekonomi yang semakin global serta kemajuan teknologi yang makin canggih, berbagai perusahaan, khususnya bank 
menghadapi peluang sekaligus risiko yakang semakin besar pada kegiatan operasionalnya. Sehingga peran manajemen risiko semakin diperlukan, karena baik bank maupun pengawas bank diseluruh dunia, semakin menyadari bahwa praktik manajemen risiko yang baik harus dilakukan, tidak hanya untuk keberhasilan suatu bank saja, namun juga untuk sistem perbankan secara keseluruhan.

Dalam menjalankan kegiatannya, bank dihadapkan pada banyak risiko diantaranya seperti yang diisyaratkan oleh Bank Indonesia, yaitu: Risiko Kredit, Risiko Pasar, dan Risiko Operasional. Dan jika bank memiliki suatu model bisnis yang lebih rumit, biasanya sejalan dengan skala usaha yang makin besar dari bank yang dimaksud maka Bank Indonesia akan meminta bank tersebut untuk mengelola: Risiko Likuiditas, Risiko Hukum, Risiko Reputasi, Risiko Strategi, dan Risiko Kepatuhan. Dari banyak risiko tersebut, yang menjadi perhatian utama Bank adalah Risiko Kredit. Hal ini dikarenakan pendapatan utama dari sebuah bank berasal dari kegiatan kredit.Tetapi bukan berarti risiko lain dapat diabaikan begitu saja. Risiko Operasional contohnya, juga layak mendapat perhatian lebih karena risiko ini dampaknya memang tidak secepat Risiko Kredit ataupun Risiko Pasar, tetapi dampaknya dapat mengganggu kelangsungan hidup sebuah bank karena baru dirasakan setelah tenggang waktu tertentu.

Dari urain diatas, dapat disimpulkan bahwa manjemen risiko memegang peranan penting terhadap kelangsungan hidup sebuah bank karena dalam menjalankan aktivitasnya, bank akan dihadapkan pada berbagai jenis risiko yang dapat terjadi kapan saja. Sementara risiko tersebut hanya bisa diminimalkan dan tidak dapat dihilangkan sama sekali.

Sesuai dengan latar belakang masalah, penulis membuat perumusan sebagai berikut: Bagaimanakah Penerapan Manajemen Risiko Operasional pada Unit Teller PT. Bank Pembangunan Daerah Sumatera Barat, Cabang Lubuk Alung.

\section{TINJAUAN PUSTAKA \\ Pengertian Bank}

Bank sebagai lembaga keuangan berfungsi sebagai menghimpun dana dari masyarakat dalam bentuk simpanan dan menyalurkannya ke dalam bentuk kredit kepada masyarakat atau pihak lain dalam rangka meningkatkan taraf hidup masyarakat. Hal ini dibangun melalui rasa saling percaya antara kedua belah pihak melalui suatu komitmen manajemen utuk menciptakan kinerja perbankan yang baik melalui terjaganya tingkat likuiditas, solvabilitas, profitabilitas pada posisi yang stabil.

Menurut Undang-undang RI Nomor 10 tahun 1998 tetang perbankan, yang dimaksud dengan bank adalah Badanusaha yang menghimpun dana dari masyarakat dalam bentuk simpanan dan menyalurkannya kepada msyarakat dalam bentuk kredit dan bentuk-bentuk lainnya dalam rangka meningkatkan taraf hidup orang banyak.

\section{Pengertian Risiko}

Risiko dapat ditafsirkan sebagai bentuk keadaan ketidakpastian tentang suatu keadaan yang akan terjadi nantinya (future) dengan keputusan yang diambil berdasarkan berbagai pertimbangan pada saat ini.

Menurut Ricky W. Griffin dan Ronald J. Ebert (1996 : 752) Risiko adalah uncertainty about future events. Adapun menurut Joel G. Siegel dan Jae K. Shim (1999: 401) mendefinisikan risiko pada tiga hal :

1. Pertama adalah keadaan yang mengarah kepada sekumpulan hasil khusus, dimana hasilnya dapat diperoleh dengan kemungkinan yang telah diketahui oleh pengambil keputusan.

2. Kedua adalah variasi dalam keuntungan, penjualan, atau variabel keuangan lainnya, dan 
3. Ketiga adalah kemungkinan dari sebuah masalah keuangan yang mempengaruhi risiko kinerja operasi perusahaan atau posisi keuangan, seperti risiko ekonomi, ketidakpastian politik, dan masalah industri.

\section{Jenis-Jenis Risiko Bank}

Dalam menjalankan fungsinya sebagai lembaga intermmediary, bank menghadapi banyak jenis risiko. Ditambah lagi dengan perkembangan perekonomian yang semakin global dan semakin canggihnya teknologi maka hal ini semakin tidak dapat untuk dihindarkan. Jenis-jenis risiko yang dihadapi oleh bank (Haris dkk, 2005: 10) saat ini adalah: (Risiko Kredit, Risiko Pasar, Risiko Likuiditas, Risiko Operasi, Risiko Kepatuhan, Risiko Reputasi)

\section{Pengertian Manajemen Risiko}

Manajemen risiko (Rivai dkk, 2007 : 822) diartikan sebagai suatu sistem pengawasan risiko dan perlindungan harta benda, harta milik, dan keuntungan badan usaha atau perorangan atau kemungkinan timbulnya kerugian karena adanya suatu risiko. Di dalam usaha, ketidakpastian ini dihubungkan dengan penghasilan perusahaan, arus keluar masuk uang dan harta benda yang telah ada, atau yang dibutuhkan di masa depan.

Manajemen risiko (Haris dkk, 2005:6) juga diterjemahkan : “ Serangkaian prosedur dan metodologi yang digunakan untuk mengidentifikasi, mengukur, memantau dan mengendalikan risiko yang timbul dari kegiatan usaha bank". Manajemen risiko merupakan sistem yang akurat dan komprehensif. Sehingga manajemen risiko mendukung accountability, performansi pengukuran dan reward, mempromosikan efisiensi operasional dari semua level.

\section{Ruang Lingkup Manajemen Risiko Perbankan}

Dewan direksi dari tiap bank mempunyai tugas untuk menetapkan bahwa risiko perbankan dalam menjalankan bisnis diatur dalam suatu tata cara yang efektif.

\section{Pengertian Manajemen Risiko Operasional}

Dalam memahami mengenai risiko operasional, terdapat banyak rumusan dengan beragam versi terhadap definisi risiko operasional. Salah satunya seperti yang terdapat dalam Basel Capital Accord II, Risiko operasional didefinisikan sebagai: “ Risiko kerugian yang terjadi sebagai akibat dari inadequate atau fail internal processes, people, dan system atau sebagai akibat dari external even ".

Dari definisi diatas dapat disimpulkan bahwa risiko operasional dapat menimbulkan pengaruh negatif yang luas karena permasalahannya berakar pada kegagalan melaksanakan dan menerapkan proses serta prosedur dalam suatu kegiatan. Hal ini mendorong perlu dilakukannya penelitian secara tajam dan luas oleh para supervisor bank terhadap setiap penerapan proses, prosedur, dan sistem yang ditetapkan dalam internal bank agar pengaruh negative dari peristiwa ekternal dapat segera dideteksi lebih awal.

\section{Identifikasi Risiko Operasional}

Tahap pertama dalam proses manajemen risiko operasional adalah mengidentifikasi risiko operasional. Perusahaan harus mengedentifikasi semua jenis dan karakteristik risiko operasional dalam setiap produk dan aktifitas usaha secara berkala kedalam lima kelompok penyebab kejadian kerugian (Muslich, 2007: 7) yaitu:

1. Kegagalan proses internal perusahaan

2. Kesalahan sumber daya manusia

3. Kegagalan sistem

4. Kerugian yang disebabkan kejadian dari luar perusahaan

5. Pelanggaran peraturan dan hukum yang berlaku 


\section{Pemantauan Risiko Operasional}

Pemantauan risiko operasional dilakukan untuk memastikan risiko operasional berada pada limit yang telah ditentukan. Bagian Manajemen Risiko harus melaksanakan pemantauan risiko operasional secara berkala terhadap seluruh eksposur risiko operasional serta kerugian (loss events) yang dapat terjadi. Dengan menerapkan sistem pengendalian internal dan menyediakan laporan berkala mengenai kerugian yang ditimbulkan oleh risiko operasional, manajemen perusahaan akan mendapatkan informasi yang jelas tentang potensi kerugian risiko operasional di masa mendatang. Bagian Manajemen Risiko harus melaksanakan pemantauan secara berkala terhadap faktor-faktor penyebab risiko operasional dan dampak yang ditimbulkan dari kerugian operasional yang dialami oleh perusahaan.

\section{Pengendalian Risiko Operasional}

Pengendalian dan mitigasi risiko operasional harus dilaksanakan oleh seluruh unit kerja dan satuan kerja perusahaan, termasuk Bagian Manajemen Risiko, dan Direksi. Manager unit kerja atau unit bisnis harus memastikan bahwa perusahaan telah memiliki kebijakan dan prosedur pengendalian dan mitigasi risiko operasional yang dipatuhi dan dilaksanakan oleh setiap unit kerja melaksanakan transaksi dan aktivitas dengan akurat, efisien, dan tepat waktu.

Bagian manajemen risiko harus memastikan bahwa setiap unit kerja telah memiliki sistem teknologi informasi yang dapat memberikan informasi secara akurat dan memadai sehingga manajemen dapat melaksanakan pemantauan dan pengendalian risiko operasional secara tepat waktu.

Manfaat Manajemen Risiko Operasional (MRO)

MRO mempunyai manfaat tinggi, namun relatif sulit untuk dilaksanakan secara efektif dalam kegiatan operasional perbankan sehari-hari. Penerapan terhadap MRO oleh bank memberi manfaat (Haris dkk, 2005 : 27) bagi Bank sebagai berikut :

1. Untuk memastikan bahwa manajemen mengambil langkah yang tepat untuk identifikasi, menilai dan mengelola Risiko Oprasional.

2. Untuk meningkatkan transparansi dan konsisten atas informasi yang berkenaan dengan MRO ke seluruh organisasi Bank dengan menyelaraskan sumber informasi seperti Key Risk Indicator, Risk Self Assessment, Corporate Loss Database dan laporan audit.

3. Untuk memfasilitasi pendekatan Risk Based Approach atas Capital Allocation untuk Risiko Operasional.

4. Untuk mengurangi kerugian operasional.

\section{METODE PENELITIAN \\ Metode Penelitian}

Dalam pengumpulan data dan bahan untuk melakukan penelitian ini, digunakan metode-metode pengumpulan data sebagai berikut :

\section{Metode Pengumpulan Data}

a. Studi Lapangan (Field Research)

Pada penelitian ini dilakukan dengan cara melakukan pengamatan langsung dan melakukan wawancara dengan pihak-pihak Bank Pembangunan Daerah Sumatera Barat Cabang Lubuk Alung

b. Studi Kepustakaan (Library Research)

Penelitian ini dilakukan dengan mengumpulkan data dan menggunakan teori-teori yang berkaitan dengan masalah-masalah yang akan dibahas, yang di peroleh dari literature yang ada berupa buku-buku yang berkaitan dengan masalah. 
c. Dokumentasi

Dokumentasi adalah metode yang digunakan untuk menelusuri data historis atau peninggalan tertulis dalam bentuk buku-buku, teori-teori dan sebagainya yang berhubungan dengan perusahaan tersebut.

\section{Metode Analisa Data}

Metode analisa data yang digunakan dalam penelitian ini adalah metode analisis kualitatif yang menjelaskan secara Deskriptif yaitu dengan menguraikan data secara sistematis dari fakta-fakta yang didapat kemudian dihubungkan dengan Penerapan Manajemen Risiko Operasional pada Unit Teller pada PT. Bank Pembangunan Daerah Sumatera Barat cabang Lubuk Alung.

\section{HASIL DAN PEMBAHASAN}

\section{Gambaran Manajemen Risiko Operasional Pada Unit Teller Bank Pembangunan} Daerah Sumatera Barat Cabang Lubuk Alung

\section{Pengawasan Aktif Komisaris}

1) Komisaris dan Direksi Bank Pembangunan Daerah Sumatera Barat cabang Lubuk Alung memahami risiko operasional dan secara aktif melakukan persetujuan serta mengevaluasi kebijakan dan strategi risiko operasional secara periodik.

2) Kebijakan dan strategi risiko operasional dengan mempertimbangkan dampaknya terhadap permodalan dengan memperhatikan perubahan eksternal dan internal.

3) Direksi menjabarkan dan mengkomunikasikan kebijakan dan strategi risiko operasional kepada seluruh satuan kerja terkait melalui Surat Edaran - Surat Edaran serta mengevaluasi penerapan kebijakan dan strategi dimaksud.

4) Direksi mengindentifikasi dan mengelola risiko operasional yang melekat pada produk dan aktivitas baru serta memastikan bahwa risiko produk dan aktivitas baru tersebut telah melalui proses pengendalian risiko yang memadai, sebelum diperkenalkan atau dijalankan.

5) Direksi memastikan penempatan dan peningkatan kompetensi serta integritas sumber daya manusia yang memadai pada seluruh aktivitas fungsional bank.

Proses Identifikasi, Pengukuran, Pemantauan dan Sistem Informasi Manajemen Risiko Operasional

1) Identifikasi Risiko Operasional

a) Bank Pembangunan Daerah (BPD) Sumatera Barat cabang lubuk alung melakukan identifikasi dan analisa terhadap faktor penyebab timbulnya risiko operasional yang melekat pada seluruh aktivitas fungsional, produk, proses dan sistem informasi, baik yang disebabkan oleh faktor intern maupun ekstern yang berdampak negatif terhadap pencapaian sasaran organisasi bank.

b) Bank BPD Sumbar cabang lubuk alung memiliki prosedur penilaian yang memadai terhadap risiko operasional yang melekat pada aktivitas dan produk baru termasuk proses dan sistemnya.

c) Hasil identifikasi tersebut selanjutnya digunakan untuk mengembangkan suatu database mengenai jenis kerugian (liss events) yang ditimbulkan oleh risiko operasional.

d) Metode yang dapat digunakan oleh Bank BPD Sumatera Barat cabang Lubuk Alung untuk mengidentifikasi risiko operasional, antara lain :

(1) Self risk assessment

(2) Risk mapping;

(3) Key risk indicators

(4) Scorecards 
2) Pengukuran Risiko Operasional

a) Setelah Bank BPD Sumatera Barat cabang Lubuk Alung melakukan identifikasi risiko operasional yang melekat pada aktivitas fungsional tertentu, Bank BPD Sumbar cabang Lubuk Alung menilai parameter yang mempengaruhi eksposur risiko operasional

b) Pengumpulan Data Risiko Operasional

c) Bank BPD Sumbar cabang Lubuk Alung mencatat dan menatausahakan setiap events termasuk jumlah potensi kerugian yang diakibatkan events dimaksud dalam suatu administrasi data.

3) Pemantauan Risiko Operasional

a) Bank BPD Sumbar cabang Lubuk Alung melakukan pemantauan risiko operasional secara berkelanjutan terhadap seluruh eksposur risiko operasional serta kerugian (loss events) yang dapat ditimbulkan oleh aktivitas fungsional utama (major business line), antara lain dengan cara menerapkan sistem pengendalian intern dan menyediakan laporan berkala mengenai kerugian yang ditimbulkan oleh risiko operasional.

b) Bank BPD Sumbar cabang Lubuk Alung melakukan review secara berkala terhadap faktor-faktor penyebab timbulnya risiko operasional serta dampak kerugiannya.

c) Satuan kerja manajemen risiko harus menyusun laporan keuangan mengenai kerugian dari risiko operasional dan hasil review kepatuhan audit intern serta penyampaian laporan tersebut kepada Komite Manajemen Risiko dan Direksi.

4) Sistem Informasi Manajemen Risiko Operasional

a) Bank BPD Sumbar cabang Lubuk Alung memiliki sistem dan teknologi informasi yang memadai, sesuai dengan sifat dan volume transaksi.

b) Sistem informasi manajemen harus dapat menghasilkan laporan yang lengkap dan akurat yang digunakan untuk pemantauan risiko dalam rangka mendeteksi dan mengoreksi penyimpangan secara tepat waktu guna mengurangi potensi terjadinyan loss events.

c) Sistem informasi manajemen harus dapat menyediakan laporan eksposur risiko operasional secara lengkap, akurat dan tepat waktu dalam rangka proses pengambilan keputusan oleh Direksi.

Pengendalian Risiko Operasional

1) Bank Pembangunan Daerah Sumatera Barat cabang Lubuk Alung memiliki kebijakan, prosedur dan proses untuk mengendalikan atau memitigasi risiko operasional, sesuai dengan kompleksitas operasional bank.

2) Dalam penerapan pengendalian risiko operasional, Bank Pembangunan Daerah Sumatera Barat cabang Lubuk Alung mengembangkan program untuk memitigasi risiko operasional antara lain pengamanan proses teknologi informasi, asuransi, dan outsourcing sebagian kegiatan operasional Bank.

3) Bank Pembangunan Daerah Sumatera Barat cabang Lubuk Alung memiliki support system,

4) Bank Pembangunan Daerah Sumatera Barat cabang Lubuk Alung melakukan kaji ulang secara berkala terhadap prosedur, dokumentasi, sistem pemrosesan data, contigency plan, dan praktek operasional lainnya guna mengurangi kemungkinan terjadinya kesalahan manusia (human error) yang menimbulkan risiko operasional. 


\section{Potensi Risiko Operasional pada Unit Teller}

Unit Teller mempunyai potensi risiko operasional yang tinggi karena berhubungan langsung dengan materi dalam hal ini uang tunai. Kesalahan yang terjadi akan berakibat fatal terhadap jumlah uang tunai di khasanah dan juga neraca. Beberapa potensi risiko yang dapat terjadi pada unit Teller meliputi :

1. Risiko adanya uang palsu.

2. Kesalahan dalam penginputan nominal dan nomor rekening pada saat transaksi.

3. Kekurangan atau kelebihan bayar kepada nasabah.

4. Kekurangan atau kelebihan pada saat menerima setoran nasabah.

5. Risiko terjadinya salah pemindahbukuan / input mutasi.

\section{Penerapan Manajemen Risiko Operasional pada Unit Teller}

Pada prakteknya Penerapan Manajemen Risiko Operasional pada unit teller dapat dilihat pada aktifitas harian yang dilakukan dengan berpedoman pada sistem dan prosedur yang telah ditetapkan. Dimulai pada pagi hari dimana head teller yang mendapat wewenang untuk masuk khasanah akan melakukan serah terima cashbox kepada masing-masing teller yang bertanggung jawab sepenuhnya atas isi masingmasing cashbox. Isi Cashbox tersebut, yaitu : uang tunai pecahan kecil yang tidak dapat disetorkan kepada head teller pada akhir hari sebelumnya.

Selanjutnya teller akan siap memulai aktivitas hariannya antara lain :

a. Menerima Setoran Tunai

Langkah-langkah yang dilakukan oleh teller, yaitu :

1. Menerima uang tunai dan slip setoran dari nasabah, lalu menghitung jumlah uang dan mencocokkan jumlah fisik uang tersebut dengan angka yang tertera pada slip setoran.

2. Kemudian teller akan menghitung uang baik dengan menggunakan mesin hitung uang maupun secara manual lalu memeriksa keaslian uang tersebut dengan menggunakan lampu UV.

3. Mencocokkan penulisan angka dan terbilang pada slip setoran, serta memverifikasi tanda tangan nasabah. Memastikan nomor rekening yang tertera pada slip setoran cocok dengan nama nasabah pada sistem komputer.

4. Jika sudah cocok, teller akan memposting slip setoran, dan memastikan nama yang tertera di system sama dengan nama yang tertera pada slip setoran.

b. Menerima Penarikan Tunai

Langkah-langkah yang dilakukan :

1. Memverifikasi tanda tangan pada slip penarikan untuk memastikan tanda tangan tersebut sama dengan yang tertera pada specimen buku tabungan untuk memastikan yang melakukan penarikan uang adalah sipemilik rekening.

2. Memeriksa penulisan angka dan terbilang.

3. Memposting dan memastikan bahwa nasabah tersebut mempunyai saldo diatas saldo minimum.

4. Membayarkan uang yang ditarik dan melakukan penghitungan di depan nasabah tersebut untuk menghindari kecurangan baik oleh teller maupun pihak nasabah.

c. Melakukan Transfer Uang

Langkah-langkah yang dilakukan :

1. Menerima slip transfer dari nasabah, memeriksa nominal dan terbilang.

2. Memverifikasi tanda tangan nasabah apabila penarikan dilakukan secara debet rekening, dan memastikan kebenaran nomor rekening dan nama. Jika dilakukan secara tunai, menghitung uang dan mencocokkan jumlah fisik uang dengan nominal yang tertera pada slip transfer. Proses lainnya sama dengan penerimaan setoran tunai. Setelah uang yang diterima "klop", teller akan mempostingkan 
jumlah uang yang akan ditransfer atau pindah bukukan jika debet rekening termasuk biaya pada sistem, lalu mengekspedisikan slip transfer ke bagian / unit yang terkait.

d. Menerima Penukaran Mata Uang Asing.

Terhadap penukaran mata uang asing, teller akan memeriksa tahun dan seri penerbitan uang tersebut, memeriksa keasliannya dengan menggunakan lampu UV, dan mempostingnya ke dalam sistem komputer.

Penerapan manajemen risiko operasional pada unit teller dilakukan dengan mengikuti sistem dan prosedur yang telah ditetapkan oleh pihak manajemen, Penerapan manajemen risiko operasional ini dilakukan untuk menghindari terjadinya risiko selisih pada kas.

\section{Antisipasi yang dilakukan Bank Pembangunan Daerah Sumatera Barat canang Lubuk Alung terhadap Risiko Operasional}

Dalam mengantisipasi kerugian yang mungkin timbul dari risiko operasional, Bank Pembangunan Daerah Sumatera Barat cabang Lubuk Alung telah melakukan beberapa tindakan antisipatif yang meliputi :

1. Sandi (password)

Masing-masing user memiliki password yang digunakan untuk masuk dan "login" pada sistem yang akan digunakan untuk menjalankan kegiatan operasional sehari-hari.

2. Pemisahan Wewenang dan Tanggung Jawab

Terdapat beberapa pemisahan wewenang dan tanggung jawab dalam hal :

1) Pemegang kunci dan kode kombinasi khasanah

2) Pemegang kunci dan kode kombinasi ruang Safe Deposit Box

3) Pemegang kunci dan kode kombinasi mesin ATM

Hal ini dilakukan dengan maksud agar terdapat dual control dan memperkecil kemungkinan terjadinya penyalahgunaan wewenang dan tanggung jawab.

\section{KESIMPULAN DAN SARAN}

\section{Kesimpulan}

1. Kegiatan operasional merupakan kegiatan yang tidak dapat dipisahkan dari sebuah perusahaan, karena tanpa kegiatan ini sebuah perusahaan tidak akan dapat menjalankan aktivitasnya.

2. Dalam penerapan pengendalian risiko operasional, Bank Pembangunan Daerah Sumatera Barat cabang Lubuk Alung mengembangkan program untuk memitigasi risiko operasional antara lain pengamanan proses teknologi informasi, asuransi, dan outsourcing sebagian kegiatan operasional Bank.

3. Unit Teller mempunyai potensi risiko operasional yang tinggi karena berhubungan langsung dengan materi dalam hal ini uang tunai. Kesalahan yang terjadi akan berakibat fatal terhadap jumlah uang tunai di khasanah dan juga neraca.

4. Proses Penerapan Manajemen Risiko Operasional pada Unit Teller PT. Bank Pembangunan Daerah Sumatera Barat cabang Lubuk Alung yang kontinue dan konsisten, merupakan proses penerapan yang sesuai dengan konsep-konsep yang ditetapkan oleh Bank Indonesia.

5. Kebijaksanaan kantor pusat PT. Bank Pemerintahan Daerah Sumatera Barat yang terus beradaptasi dengan situasi lingkungan terkini dan terus menerus memberikan informasi dan petunjuk kepada bidang-bidang yang melakukan kegiatan operasional merupakan langkah strategis untuk mempertahankan kelangsungan 
hidup perusahaan dengan menekan tingkat risiko operasional sehingga biaya Saran

(cost) yang ditimbulkan dari risiko ini dapat diminimalkan.

Penerapan Manajemen Risiko Operasional pada unit Teller agar dapat terus dilakukan mengingat unit-unit ini merupakan bagian perusahaan yang melakukan kegiatan operasional yang berhubungan langsung dengan pihak luar (nasabah), karena kerugian yang ditimbulkan akibat risiko operasional pada unit Teller tidak saja berpengaruh secara finansial. Tetapi juga non finansial karena berhubungan dengan citra bank dimata nasabah.

Pengawasan yang lebih ketat terhadap Penerapan Manajemen Risiko Operasional sangat penting dilakukan untuk menghindarkan Bank Pembangunan Daerah Sumatera Barat cabang Lubuk Alung dari risiko kerugian lebih besar yang timbul dari kegiatan operasional, mengingat misi Bank Pembangunan Daerah Sumatera Barat cabang Lubuk Alung Memenuhi dan menjaga kepentingan stakeholder secara konsisten dan seimbang yang berarti Bank BPD Sumatera Barat cabang Lubuk Alung akan senantiasa dijalankan dengan prinsip untuk memenuhi tanggung jawab kepada pemilik, nasabah, karyawan, dan masyarakat.

\section{DAFTAR PUSTAKA}

Amelia, L., \& Marlius, D. (2018). Pengendalian Kredit Dalam Upaya Menciptakan Bank Yang Sehat Pada PT. Bank Pembangunan Daerah Sumatera Barat Cabang Utama Padang. https://doi.org/10.31227/osf.io/kpc64

Bank Indonesia. 2004. Booklet Perbankan Indonesia 2004. Direktorat Perizinan dan Informasi Perbankan Bank Indonesia. Jakarta

Haris, Arifin S. 2005. Manajemen Risiko dan Manajemen Risiko Perbankan. Prima Management Consultan. Jakarta

Husein Umar. 2001. Manajemen Risiko Bisnis, Pendekatan Finansial dan Non Finansial. PT. Gramedia Pustaka Utama. Jakarta

Idroes, Ferry N. 2006. Manajemen Risiko Perbankan. Graha Ilmu. Jakarta

Joel G. Siegel dan Jae K. Shim. 1999. Kamus Istilah Akuntansi. Elex Media Komputindo. Jakarta

Mamduh M. Hanafi. 2006. Manajemen Risiko. UPP STIM YKPN. Yogyakarta

Muslich, Muhammad, Dr, M.B.A. 2007. Manajemen Risiko Operasional. Bumi Aksara. Jakarta

Ricky W. Griffin dan Ronald J. Ebert. 1996. Business. Prentice Hall International Edition.

Rivai, Veithzal. 2007. Bank and Financial Institution Management. Rajawali Pers. Jakarta

Sutaryono, Paul. 2003. Manajemen Risiko Operasional dan Upaya Mengatasi Pembobolan

Bank. Kompas. Jakarta 
Triandaru, Sigit \& Budisantoso, Totok. 2006. Bank dan Lembaga Keuangan Lainnya edisi 2. Salemba Empat

Undang - Undang RI No. 10 tahun 1998 Tentang Perbankan. Sinar Grafika 